\title{
RELEVANSI KONSEP PERPAJAKAN MENURUT ABU YUSUF DAN IBNU KHALDUN TERHADAP PEREKONOMIAN DI INDONESIA
}

\author{
Misbahul Ali \\ memesaly78@gmail.com \\ Universitas Ibrahimy Situbondo
}

\begin{abstract}
ABSTRAKC
Tax is one of the most important instruments in the development of a country. This is because the development budget and government operations have a heavy dependence on taxes. However, at this time, the ratio of tax revenue in Indonesia is relatively small. This of course will have a bad impact on the country's development, given the expenditure budget whose contribution ratio is getting bigger. The lack of tax revenue is caused by a lack of public awareness in paying taxes and the rampant corrupt practices that exist in this country. Abu Yusuf and Ibn Khaldun with their intellect which is based on Islamic teachings by considering mashlahah and justice, managed to come up with tax theories that are relevant to the economy in Indonesia today. There are several tax theories according to Abu Yusuf and Ibn Khaldun which are considered relevant and can be a solution for the economy in Indonesia. Among them, the muqasamah system if applied today is still very relevant, especially the self-assessment system currently in effect in Indonesia that allows taxpayers to cheat. The Usyur that was in effect at the time of Abu Yusuf if it is relevant to the present, has several similarities with the collection of customs taxes.
\end{abstract}

Keywords: The Concept of Taxation, the Economy in Indonesia, Abu Yusuf and Ibnu Khaldun

\section{PENDAHULUAN}

Beberapa tahun belakangan ini, negara kita dihebohkan dengan munculnya kembali program 'tax amnesty' atau pengampuan pajak dalam sistem perpajakan di Indonesia. Tax amnesty merupakan sebuah kesempatan berbatas waktu bagi kelompok wajib pajak tertentu untuk membayar pajak dengan jumlah tertentu sebagai pengampunan atas kewajiban membayar pajak (termasuk dihapuskannya bunga dan denda) yang berkaitan dengan masa pajak sebelumnya tanpa takut penuntutan pidana (Wikipedia, 2020). Hal ini berawal dari kurangnya kesadaran masyarakat di dalam membayar pajak, bahkan di kalangan elit sekalipun. 
Tak bisa dipungkiri, pajak sebagai mesin penghasil uang negara telah menjadi primadona penerimaan negara semenjak berakhirnya era kejayaan minyak yang dulu berfungsi sebagai penghasil utama penerimaan negara. Namun, hingga saat ini permasalahan pajak di Indonesia tidak henti-hentinya muncul. Padahal pajak merupakan suatu kewajiban masyarakat sebagai warga negara, tetapi masih banyak masyarakat yang tidak membayar pajak. Bahkan banyak perusahaan-perusahaan di Indonesia yang menggelapkan dan terlibat dalam kasus pajak (ceritaperpajakanindonesia.blogspot.co.id, 2020).

Perpajakan di Indonesia dimulai sebelum kedatangan bangsa Eropa, Kerajaan seperti Mataram, Kediri, Majapahit dan Pajang sudah mengenal bentuk pajak tanah dan pajak tidak langsung terhadap barang dagangan. Pejabat kerajaan pemungut pajak tidak digaji oleh kerajaan, maka seringkali mereka menerapkan pajak secara berlebihan. Upeti perorangan ataupun kelompok orang yang diberikan kepada raja atau penguasa sebagai suatu bentuk penghormatan dan tunduk patuh kepada kekuasaan raja atau penguasa suatu wilayah di Indonesia merupakan bentuk pada zaman kerajaan - kerajaan di Indonesia tumbuh. Upeti tersebut berupa hasil bumi, dan pemajakan barang perdagangan. Sebagai imbalannya maka rakyat mendapat pelayanan keamanan dan jaminan ketertiban. Kerajaan Mataram serta raja - raja sudah melaksanakan hidup swasembada dan otonom (Siti Kurnia Rahayu, 2009).

Belanja negara di Indonesia sangat ditopang dari sumber penerimaan pajak, hal ini tercermin dari sumber pendanaan belanja negara yang berasal dari rasio kontribusinya semakin besar. Sebaliknya penerimaan negara dari sumber nonpajak relatif kecil dan rasio kontribusinya terhadap belanja negara juga semakin mengecil. Belanja negara pada dasarnya dimaksudkan untuk mendukung kelancaran pelaksanaan tugas-tugas umum pemerintahan dan kegiatan operasional pemerintahan, baik di tingkat pusat maupun daerah, pembayaran bunga utang dalam dan luar negeri, pembiayaan subsidi, serta pembiayaan proyek-proyek pembangunan (Nurul Huda, 2011).

Pendapatan pajak yang dipungut dari masyarakat seharusnya dikembalikan lagi ke masyarakat dalam bentuk keadilan dan kesejahteraan serta kemakmuran maka pendistribusian harus dengan tepat tanpa ada yang keliru. Baik kebijakan pemerintah 
dalam memungut pelaksanaan pajak serta kebijakan pengeluaran yang dilakukan pemerintah pada public (Abdul Hasis, 2010).

Penulis menemukan teori-teori mengenai konsep perpajakan yang berasal dari para cendekiawan muslim. Konsep ini dipandang relevan dan bisa menjadi sebuah kajian dalam membangun konsep perpajakan. Selain itu, berkembang dan semakin diminatinya sistem perekonomian Islami akhir-akhir ini menjadi sebuah catatan bahwa sesungguhnya Islam merupakan agama yang mencakup semua lini kehidupan.

Islam muncul sebagai sumber kekuatan yang baru pada Abad ke-7 Masehi, menyusul runtuhnya kekaisaran Romawi. Kemunculan itu ditandai dengan berkembangnya peradaban baru yang sangat mengagumkan. Kebudayaan, ilmu pengetahuan, dan teknologi serta kehidupan sosial lainnya termasuk ekonomi berkembang secara menakjubkan.

Fakta sejarah itu sesungguhnya menunjukkan bahwa Islam merupakan sistem kehidupan yang bersifat komprehensif, yang mengatur semua aspek, baik dalam sosial, ekonomi, dan politik maupun kehidupan yang bersifat spiritual (Mustafa Edwin Nasution, 2015).

Firman Allah dalam al-Qur'an, surah al-Baqarah (2) ayat 1-3 :

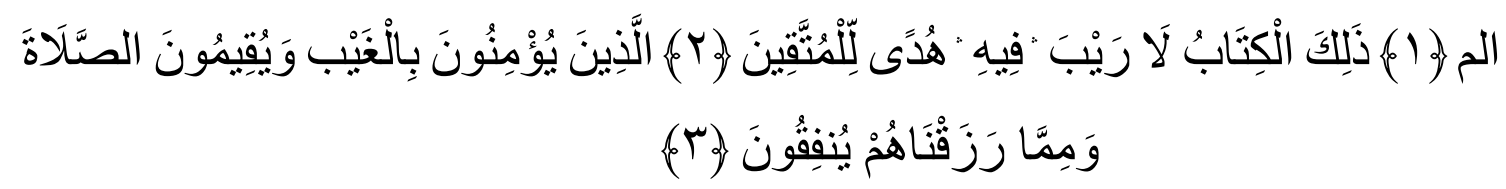

Artinya:"Alif lam mim, Kitab (Al-Qur'an) ini tidak ada keraguan padanya; petunjuk bagi mereka yang bertaqwa, (yaitu) mereka yang beriman kepada yang ghaib, yang mendirikan shalat, dan menafkahkan sebagian rezeki yang Kami anugerahkan kepada mereka." (Departemen Agama RI, 2011).

Ayat di atas menunjukkan adanya fakta sejarah (bukti empirik) yang dapat dipahami bahwa Islam merupakan sistem kehidupan yang bersifat komprehensif, yang mengatur dua aspek kehidupan yaitu duniawi yang berbentuk kehidupan sosial, ekonomi, dan sebagainya dan yang bersifat spiritual atau ukhrawi yang berbentuk kebahagiaan akhirat (Moh. Asra Maksum, Musirin, 2013).

Kontribusi kaum Muslimin yang sangat besar terhadap kelangsungan dan perkembangan pemikiran ekonomi pada khususnya dan peradaban dunia pada umumnya, telah diabaikan oleh para ilmuwan Barat. Buku-buku teks ekonomi Barat hampir tidak 
pernah menyebutkan peranan kaum Muslimin ini. Menurut Chapra, meskipun sebagian kesalahan terletak di tangan umat Islam karena tidak mengartikulasikan secara memadai kontribusi kaum Muslimin (Adiwarman Azwar Karim, 2014).

Keberhasilan para ilmuwan Muslim menciptakan pemikiran ekonomi Islam tidak lain adalah karena al-Qur'an as-Sunnah sendiri menjadi rujukan yang paling otentik bagi para intelektual Muslim klasik dalam membangun pemikiran-pemikiran ekonomi mereka dengan berbagai metodologi yang dikembangkan menurut cara-cara mereka sendiri. Atau dengan kata lain, filsafat Yunani sebenarnya hanya meramaikan kegairahan berpikir yang sebenarnya sudah tumbuh sejak awal perkembangan Islam, bahkan sejak masa kehidupan Nabi Muhammad SAW. Jadi, kontribusi Islam terhadap sejarah ekonomi modern sebenarnya sudah diberikan sejak awal mula perkembangan Islam (Arif Hoetoro, 2007).

Banyak orang yang menilai -termasuk dari kalangan intelektual Barat sendiribahwa penelitian pemikiran ekonomi menurut tradisi telah menghapus sumber-sumber pengetahuan paling berharga yang berkembang selama abad pertengahan, yaitu masa ketika kebudayaan Islam mencapai zaman keemasannya (The Golden Age of Islam). Di masa itu, sementara Barat mengalami kegelapan intelektual yang paling parah, Islam justru menghadirkan bangunan kebudayaan dan peradaban yang sangat mengagumkan. Khusus di bidang ekonomi, tulisan-tulisan tentang ekonomi telah muncul sejak awal perkembangan Islam, yaitu ketika Abu Yusuf menulis kitab al-Kharaj atau buku tentang perpajakan di tahun $182 \mathrm{H} / 762 \mathrm{M}$ (Arif Hoetoro, 2007).

Abu Yusuf adalah salah seorang ahli ekonomi yang tersohor pada generasi pertama. Ketenarannya dipengaruhi oleh satu sisi adalah murid Imam Abu Hanifah, di sisi lain adalah karyanya yang monumental, yaitu kitab Al-Kharaj. Buku tersebut menjadi salah satu referensi tentang pendapatan publik dalam negara Islam selain itu juga mencakup gagasan-gagasan ekonomi baik makro maupun mikro (Arif Hoetoro, 2007).

Dalam hal perpajakan, Abu Yusuf telah meletakkan prinsip-prinsip yang jelas yang berabad-abad kemudian dikenal oleh para ahli ekonomi sebagai canons of taxation. Kesanggupan membayar, pemberian waktu yang longgar bagi pembayar pajak dan sentralisasi pembuatan keputusan dalam administrasi pajak adalah beberapa prinsip yang ditekankannya (Boedi Abdullah, 2010). 
Abu Yusuf mengubah sistem wazifah dalam pemungutan pajak menjadi sistem muqasamah sebagai sebuah sistem yang adil terhadap masyarakat di masa pemerintahan khalifah Harun Al-Rasyid (Abu Yusuf Ya'qub bin Ibrahim bin Habib Al-Anshary AlKufy Al-Baghdadi, 2016).

Wazifah dan muqasamah merupakan istilah dalam membahasakan sistem pemungutan pajak. Wazifah memberikan arti bahwa sistem pemungutan yang ditentukan berdasarkan nilai tetap, tanpa membedakan ukuran tingkat kemampuan wajib pajak atau mungkin dapat dibahasakan dengan pajak yang dipungut dengan ketentuan jumlah yang sama secara keseluruhan, sedangkan muqasamah merupakan sistem pemungutan pajak yang diberlakukan berdasarkan nilai yang tidak tetap (berubah) dengan mempertimbangkan tingkat kemampuan dan persentase penghasilan atau pajak proporsional (M. Nazori Majid, 2003).

Selain beliau, Ibnu Khaldun juga memiliki pandangan terkait dengan kebijakan mengenai perpajakan. Beliau mengungkapkan:

"Ketika pendapatan dan gaji yang dibebankan atas rakyat itu sedikit, maka mereka bersemangat dan senang bekerja. Hasilnya akan banyak pembangunan dan semakin bertambah hasil dari semangat itu akibat sedikitnya beban. Ketika pembangunan telah banyak maka banyak juga jumlah gaji-gaji dan pendapatanpendapatan itu. Akibatnya pajak juga menjadi banyak karena ia merupakan bagian dari pembangunan" (Ibnu Khaldun, 2003).

Ibnu Khaldun juga menuliskan bahwa pajak harus dikenakan secara proposional, sesuai dengan kemampuan pembayar pajak, sedangkan pajak tak langsung seperti PPN (Pajak Pertambahan Nilai) yang mengikis daya beli masyarakat hendaknya ditiadakan, kerena dengan peniadaan pajak PPN akan menurunkan harga barang secara spontan, sehingga permintaan akan meningkat. Dengan adanya interaksi antara permintaan dan penawaran akan menciptakan keuntungan pada perusahaan, yang selanjutnya akan di pungut pajaknya oleh administrasi perpajakan yang rapi dan jujur, sehingga penerimaan negara pun menjadi meningkat.

Dalam hal pengelolaan pajak di atas, teori-teori yang dicetuskan oleh Abu Yusuf dan Ibnu Khaldun memiliki titik tekan "adil" dan berdasarkan kepada maslahah, baik bagi pemerintahan itu sendiri maupun bagi masyarakat.

\section{KAJIAN TEORI}




\section{Biografi Abu Yusuf}

Nama lengkap Beliau adalah Ya'qub bin Ibrahim bin Habib Khunais Bin Sa'ad al-Anshari al-Jalbi al-Kufi al-Baghdadi, atau yang lebih dikenal sebagai Abu Yusuf. Dilahirkan di Kufah pada tahun 113 H (731 M) dan meninggal dunia di Baghdad pada tahun 182 H (798 M). Dari nasab ibunya, ia masih mempunyai hubungan darah dengan salah seorang sahabat Rasulullah SAW., Sa'ad al-Anshari. Keluarganya sendiri bukan berasal dari lingkungan berada. Namun demikian, sejak kecil, ia mempunyai minat yang sangat kuat terhadap ilmu pengetahuan. Hal ini tampak dipengaruhi oleh suasana Kufah yang ketika itu merupakan salah satu pusat peradaban Islam, tempat para cendekiawan Muslim dari seluruh penjuru dunia Islam datang silih berganti untuk saling bertukar pikiran tentang berbagai bidang keilmuan.

Abu Yusuf menimba berbagai ilmu kepada banyak ulama besar, seperti Muhammad Atho bin as-Saib Al-Kufi, Sulaiman bin Mahran Al-A'masy, Hisyam bin Urwah, Muhammad bin Abdurrahman bin Abi Laila, Muhammad bin Ishaq bin Yassar bin Jabbar, dan Al-Hajjaj bin Arthah. Selain ia juga menuntut ilmu kepada Abu Hanifah hingga yang terakhir namanya disebut ini meninggal dunia. Selama tujuh belas tahun, Abu Yusuf tiada henti-hentinya belajar kepada pendiri madzhab Hanafi tersebut. Ia pun terkenal sebagai salah satu murid terkemuka Abu Hanifah. Sepeninggal gurunya, Abu Yusuf bersama Muhammad bin Al-Hasan Al-Syaibani menjadi tokoh pelopor dalam menyebarkan dan mengembangkan madzhab Hanafi (Adiwarman A. Karim, 2004).

Masa dewasa Abu Yusuf dilalui selama periode puncak dinasti Abbasiyah, terutama ketika Harun Al-Rasyid memerintah kekhalifahan (763-806 M). Baghdad di masa itu adalah sebuah empirium yang besar: membentang dari Cina dan India di timur hingga sahara Libia di barat, dan dari sungai Sabaun dan gunung Kafakaz di utara hingga Yaman dan Afrika Tengah di selatan. Tidak ada sebuah kerajaan manapun yang melebihi kebesaran Abbasiyah, sampai-sampai para pembesar / raja Eropa dan India sering mengirim hadiah-hadiah yang indah kepada khalifah. Di dalam kekuasaan negara yang begitu luas, jurisprudensi Islam tengah mengalami proses kompilasi dari sumbernya, yakni al-Qur'an dan as-Sunnah yang mempresentasikannya sebagai hukum nasional (Arif Hoetoro, 2007). 
Dengan ilmunya yang sempurna, yang beliau peroleh sejak kecil dari gurunya yang bernama Abu Hanifah, dalam waktu yang tidak cukup lama, Abu Yusuf mendapatkan posisi strategis di pemerintahan Baghdad. Awalnya beliau menjadi hakim yang mengurusi hukum-hukum Islam. Kejujuran beliau, konsisten, luasnya ilmu, kuatnya pemikiran yang beliau miliki dan kelembutan sikap menjadikan beliau mendapatkan amanah menjadi "Qadli Qudhoh", "hakimnya para hakim” seluruh negara-negara yang berada di bawah kekuasaan Islam seluruh dunia. Beliaulah yang menjadi orang pertama yang memimpin para hakim umat Islam (Nurul Huda \& Ahmad Muti, 2011).

Kitab Al-Kharaj ditulis Abu Yusuf sebagai jawaban atas persoalan kenegaraan yang dihadapi oleh khalifah Harun Al-Rasyid yang sangat menginginkan terciptanya kebaikan umum atas dasar syari'at dan keadilan sosial. Al-Rasyid sering mengajukan pertanyaan-pertanyaan yang terkait dengan politik, administrasi, dan urusan fiskal negara. Namun yang menjadi konsentrasi utamanya adalah masalah perpajakan dan belanja negara (Arif Hoetoro, 2007).

Dengan latar belakang sebagai seorang fuqaha beraliran ahl ar-ra'yu, Abu Yusuf cenderung memaparkan berbagai pemikiran ekonominya dengan menggunakan perangkat analisis qiyas yang didahului dengan melakukan kajian yang mendalam terhadap al-Qur'an, Hadits nabi, Atsar Shahabi, serta praktik para penguasa yang saleh. Landasan pemikirannya, seperti yang telah disinggung adalah mewujudkan al-maslahah al- 'ammah (kemaslahatan umum). Pendekatan ini membuat berbagai gagasannya lebih relevan dan mantap (Adiwarman A. Karim, 2004).

\section{Biografi Ibnu Khaldun}

Ibnu Khaldun dilahirkan di Tunisia pada awal bulan Ramadhan 732 H (27 Mei 1332 M). Dan Ia Wafat pada tanggal 26 Ramadhan 808 H. (16 Maret 1406 M) tak lama setelah ditunjuk sebagai hakim. Dia dikebumikan dikawasan pemakaman orang sufi di Kairo (Adiwarman A. Karim, 2004).

Ia mempunyai nama lengkap Abdurrahman Abu Ziad Waliuddin Ibnu Khaldun. Abdurrahman adalah nama kecilnya dan Abu Zaid adalah nama panggilan keluarganya, sedangkan Waliuddin gelar yang diberikan kepadanya sewaktu Ia menjabat sebagai qodhi di Mesir. Selanjutnya Ia lebih populer dengan sebutan Ibnu Khaldun. Berdasarkan silsilahnya, Ibnu Khaldun mempunyai hubungan darah dengan Wail bin Hajar, salah 
seorang sahabat Nabi yang terkemuka. Keluarga Ibnu Khaldun yang berasal dari Hadramaut, Yaman ini, terkenal sebagai keluarga yang berpengetahuan luas dan berpangkat serta menduduki berbagai jabatan tinggi kenegaraan (Adiwarman A. Karim, 2004).

Seperti halnya tradisi yang sedang berkembang dimasa itu, Ibnu Khaldun mengawali pelajaran dari ayah kandungnya sendiri. Setelah itu, ia pergi berguru kepada para ulama terkemuka, seperti Abu Abdillah Muhammad bin Al-Arabi, Abu Al-Abbas Ahmad ibn Al-Qushshar, Abu Abdillah Muhammad Al- Jiyani, dan Abu Abdillah Muhammad Ibn Ibrahim Al-Abili, untuk mempelajari berbagai ilmu pengetahuan, seperti tata bahasa Arab, hadis, fiqih, teologi, logika, ilmu kalam, matematika dan Astronomi.

Sebagai anggota dari keluarga Aristocrat, Ibnu Khaldun sudah ditakdirkan untuk menduduki jabatan tertinggi dalam administrasi Negara dan mengambil bagian dalam hampir semua pertikaian politik di Afrika Utara. Namun karena pengaruh budaya Spanyol yang sempat melekat dalam kehidupan keluarga dan dirinya selama satu abad, Ibnu Khaldun tidak pernah menjadi "anggota penuh" dari masyarakatnya dan tetap hanya menjadi pengamat luar dari dunianya (Sayri, 2017).

Di Tunis keluarganya menetap setelah pindah dari Spanyol Moor. Selama empat tahun di tempat itu ia menyelesaikan Muqaddimah, tahun 1337 M kemudian pindah ke Tunis untuk menyelesaikan kitab al-I'bar (sejarah dunia) dengan perolehan bahan-bahan dari perpustakaan kerajaan (Nur Chamid, 2010).

Karena ilmunya yang sangat luas dan dalam, ia diakui banyak pihak sebagai bapak ilmu ekonomi, sosiologi, sejarah, dan cabang-cabang ilmu sosial lainnya. Kontribusinya untuk ilmu pengetahuan sosial tidak hanya terletak pada orisinalitas gagasan dan isi, namun juga dalam metodologi, oleh karena dialah yang mempelopori penilitian empiris dalam kajian peradaban umat manusia. Tulisan Ibnu Khaldun memang jauh dari analisis teologi sebagaimana umumnya berkembang di masa itu, tetapi lebih analitis dan empiris.

Dari tahun 1375 s/d 1378 M, ia mulai menjalani masa pensiunnya di Gal'at Ibn Salamah, sebuah puri di Propinsi Oran. Ia mulai menulis sejarah dengan menyusun Muqaddimah sebagai volume pertamanya. Karena alasan ingin mencari buku-buku di berbagai perpustakaan besar, pada tahun $1378 \mathrm{M}$, ia mendapatkan izin dari pemerintah Hafsid untuk kembali ke Tunisia. Di sana, hingga tahun $1382 \mathrm{M}$, ketika berangkat ke 
Iskandariah, ia menjadi guru besar ilmu hukum. Sisa-sisa hidupnya dihabiskan di Kairo hingga wafat pada tanggal 17 Maret 1406 M (Bahrul Ulum, 2016).

Para sejarawan umumnya mengakhiri pembahasan mengenai intelektualisme Islam klasik pada era Ibnu Khaldun. Hal ini dikarenakan setelah ia wafat, tidak ditemukan lagi karya-karya intelektual Islam yang hebat (Arif Hoetoro, 2007).

\section{Konsep Perpajakan Menurut Abu Yusuf}

Dalam sejarah ekonomi Islam Abu Yusuf dikenal memilki sumbangan yang cukup besar terhadap kemajuan ekonomi pada masa kepemimpinan Khalifah Harun arRasyid, beliau meletakkan dasar-dasar kebijakan fiskal yang berbasis kepada keadilan dan maslahah.

Kekuatan utama pemikiran Abu Yusuf adalah dalam masalah keuangan publik. Dengan daya observasi dan analisisnya yang tinggi, Abu Yusuf menguraikan masalah keuangan dan menunjukkan beberapa kebijakan yang harus diadopsi untuk meningkatkan pertumbuhan ekonomi dan kesejahteraan rakyat (Muhammad Fauzan, 2017).

Adapun ukuran mashlahah menurut Abu Yusuf dapat diukur dari beberapa aspek, yaitu keseimbangan (tawazun), kehendak bebas (al-ikhtiar), tanggung jawab / keadilan (al-'adalah) atau accountability, dan berbuat baik (al-ikhsan). Jika konsepsi mashlahah yang dipakai oleh Abu Yusuf adalah konsepsi As-Syatibi, maka teori analisis ekonominya dikategorikan sebagai bentuk dari al-mashlahah al-mu'tabarah (Nurul Huda \& Ahmad Muti, 2011).

Pembahasan mengenai pajak dalam kitab Al-Kharaj Abu Yusuf, menjadi bahasan yang paling dominan, dari mulai restrukturisasi mekanisme pemungutannya sampai dengan rinci. Beliau menjelaskan tentang manajemen pengelolaan pajak dan kriteria orang yang layak dijadikan pegawai pajak (Nurul Huda \& Ahmad Muti, 2011).

Adapun jenis-jenis pajak yang dipungut pada masa Abu Yusuf adalah fay'i, kharaj, usyur dan jizyah. Ibnu Taimiyah menjelaskan seluruh sumber pendapatan di luar ghanimah dan sedekah adalah fay'I (Gusfahmi, 2007).

Harta fay'i meliputi kharaj, jizyah, usyur ataupun harta perdamaian. Harta fay'i merupakan sumber dana umum yang diperuntukkan bagi Rasul dan pemerintahan serta pihak lain yang bertugas untuk mewujudkan kemashlahatan kehidupan kaum Muslimin. 
Secara literasi, jizyah berasal dari kata jaza yang berarti imbalan, secara aturan syari'at jizyah dapat diartikan sejumlah harta yang diwajibkan atas kafir dzimmi, yaitu orang yang masuk dalam lindungan dan kekuasaan kaum Muslimin. Ia menjadi imbalan atas perlindungan yang diberikan pemerintahan Islam kepada kafir dzimmi, jika mereka sepakat maka terbebas dan dapat hidup bersama dengan kaum Muslimin.

Usyur merupakan jenis pemasukan negara yang dihasilkan dari perdagangan internasional dan dapat didefinisikan sebagai harta yang diambil oleh petugas negara dari para pedagang yang melintasi wilayah kekuasaan Islam.

Ghanimah adalah harta yang diambil dari orang kafir harbi secara paksa melalui peperangan atau pertempuran fisik (Nurul Huda \& Ahmad Muti, 2011).

Kharaj menurut bahasa bermakna al-kara' (sewa) dan al-ghullal (hasil). Setiap tanah yang diambil dari kaum kafir secara paksa, setelah perang diumumkan kepada mereka, dianggap sebagai tanah kharajiyah. Jika mereka memeluk Islam, setelah penaklukan tersebut, maka status tanah mereka tetap kharajiyah. Kharaj adalah hak yang diberikan atas lahan tanah yang telah dirampas dari tangan kaum kafir, baik dengan cara perang maupun damai. Jika perdamaian menyepakati bahwa tanah tersebut milik kita dan mereka pun mengakuinya dengan membayar kharaj, maka mereka harus menunaikannya.

Dalam hal perpajakan, Abu Yusuf telah meletakkan prinsip-prinsip yang jelas beabad-abad kemudian dikenal oleh para ahli ekonomi sebagai canon of taxation. Kesanggupan membayar, pemberian waktu yang longgar bagi pembayar pajak, dan sentralisasi pembuatan keputusan dalam administrasi pajak merupakan beberapa prinsip yang ditekannya (Boedi Abdullah, 2010).

Subjek utama Abu Yusuf adalah perpajakan dan tanggung jawab ekonomi dari negara. Sumbangannya terletak pada pembuktian keunggulan pajak berimbang terhadap sistem pungutan tetap atas tanah, keduanya ditinjau dari segi pandangan dan keadilan.

Abu Yusuf mengubah sistem wazifah dalam pemungutan pajak menjadi sistem muqasamah sebagai sebuah sistem yang adil terhadap masyarakat di masa pemerintahan khalifah Harun Al-Rasyid (Abu Yusuf, Ya'qub bin Ibrahim bin Habib Al-Anshary AlKufy Al-Baghdadi, 2016).

Perubahan sistem muqasamah ini dibahas dalam bab yang berjudul " $F i$ Maa Yanbaghi an Yu'mal Bihi Fis sawad'. Bagi Abu Yusuf, mengubah sistem berarti 
mengubah tatanan perekonomian yang lama. Oleh karenanya, Abu Yusuf tidak sembarangan dalam hal ini.

Wazifah dan muqasamah merupakan istilah dalam membahasakan sistem pemungutan pajak. Wazifah memberikan arti bahwa sistem pemungutan yang ditentukan berdasarkan nilai tetap, tanpa membedakan ukuran tingkat kemampuan wajib pajak atau mungkin dapat dibahasakan dengan pajak yang dipungut dengan ketentuan jumlah yang sama secara keseluruhan, sedangkan muqasamah merupakan sistem pemungutan pajak yang diberlakukan berdasarkan nilai yang tidak tetap (berubah) dengan mempertimbangkan tingkat kemampuan dan persentase penghasilan atau pajak proporsional (M. Nazori Majid, 2003).

Dalam hal administrasi kharaj, Abu Yusuf menolak praktik taqbil, yaitu sistem pengumpulan kharaj dimana seseorang dari penduduk lokal biasanya mengajukan diri kepada penguasa untuk bertanggung jawab dalam memungut dan menghimpun kharaj di wilayahnya. Dia sendiri yang menemukan target penerimaan, sementara pemerintah lokal cukup menerima hasilnya sebagai penerimaan bersih (Abu Yusuf, Ya'qub bin Ibrahim bin Habib Al-Anshary Al-Kufy Al-Baghdadi, 2016).

Abu Yusuf menekankan pentingnya sifat amanah dalam mengelola uang negara, uang negara bukan milik Khalifah, tetapi amanat Allah dan rakyatnya yang harus dijaga dengan penuh tanggung jawab. Ia sangat menentang pajak atas tanah pertanian dan mengusulkan penggantian sistem pajak tetap (lump sum system) ${ }^{1}$ atas tanah menjadi sistem pajak proporsional (proportional system) ${ }^{2}$ atas hasil pertanian. Sistem proporsional ini lebih mencerminkan rasa keadilan serta mampu menjadi automatic stabilizer bagi perekonomian sehingga dalam jangka panjang perekonomian tidak akan berfluktuasi terlalu tajam.

Dalam hal penetapan pajak, Abu Yusuf cenderung menyetujui negara mengambil bagian dari hasil pertanian dari para penggarap daripada menarik sewa dari lahan pertanian. Menurutnya, cara ini lebih adil dan memberikan hasil produksi yang lebih besar dengan memberikan kemudahan dalam memperluas tanah garapan (Boedi Abdullah, 2010).

\footnotetext{
${ }^{1}$ Lump sum system disebut juga dengan sistem wazifah.

${ }^{2}$ Proportional system disebut juga dengan sistem muqasamah.
} 
Abu Yusuf melihat bahwa pada masanya ada wilayah yang tidak ditanami selama ratusan tahun dan para petani tidak mempunyai kemampuan untuk menghidupkannya. Dalam situasi demikian, pajak yang menetapkan ukuran panen yang pasti atau jumlah uang tunai yang pasti akan membebani para pembayar pajak dan hal itu dapat mengganggu kepentingan keuangan publik.

Abu Yusuf menunjukkan bahwa jumlah pajak yang pasti berdasarkan ukuran tanah (baik yang ditanami maupun tidak) dibenarkan hanya jika tanah tersebut subur. Oleh karena itu, tidak dibenarkan untuk membebani pajak yang pasti tanpa mempertimbangkan kesuburan tanah tersebut karena hal itu akan mempengaruhi para pemilik tanah yang tidak subur.

Dalam perekonomian yang berhubungan dengan perpajakan, Abu Yusuf juga membangun fleksibilitas sosial. Abu Yusuf mewajibkan warga negara non-muslim pada saat itu untuk membayar pajak. Beliau memandang bahwa warga negara sama di hadapan hukum, sekalipun beragama non-Islam. Dalam hal ini, Abu Yusuf membagi tiga golongan orang yang tidak memiliki kapasitas hukum secara penuh, yaitu harbi, musta'min dan dzimmi. Kelompok musta'min dan dzimmi adalah kelompok asing yang berada di wilayah kekuasaan Islam dan membutuhkan perlindungan keamanan dari pemerintah Islam serta tunduk dengan segala aturan hukum yang berlaku. Perhatian ini, diberikan Abu Yusuf dalam rangka memberi pemahaman keseimbangan serta persamaan hak dan juga mekanisme penetapan pajak jizyah.

Jizyah tidak diberlakukan bagi perempuan, anak-anak, orang miskin dan kalangan tidak mampu. Bagi yang tidak mampu membayar mereka juga wajib dilindungi dan disantuni. Hal ini kiranya lebih mengarah pada keseimbangan dan nilai-nilai keadilan yang manusiawi. Ini dilakukan sebagai ukuran material dan kemampuan masyarakat dalam menunaikan kewajibannya sebagai warga negara (Abu Yusuf, Ya'qub bin Ibrahim bin Habib Al-Anshary Al-Kufy Al-Baghdadi, 2016).

Dalam pengumpulan bea, Abu Yusuf mensyaratkan dua hal yang harus dipertimbangkan. Pertama, barang-barang tersebut adalah barang-barang yang dimaksudkan untuk diperdagangkan. Kedua, nilai barang yang dibawa tidak kurang dari 200 dirham. Dalam hal pendistribusian pendapatan negara, Abu Yusuf mengingatkan hendaknya hal tersebut ditujukan demi mewujudkan kesejahteraan masyarakat. Al-Quran 
sendiri telah memerintahkan agar pendistribusian harta dilakukan secara adil dan tidak menumpuk di tangan segelintir orang.

Dalam rangka tawliyatul kharaj (pengelolaan pajak kharaj) yang lebih baik dan professional, Abu Yusuf berpendapat bahwa harus ada kriteria khusus bagi pengelola pajak, seperti harus ahli fiqh, alim, suka bermusyawarah kepada para ahli, menjaga harga diri, aibnya tidak pernah terlihat di depan umum, tidak takut celaan orang-orang, menjaga hak dan menunaikan amanah dengan mengharap surga.

Abu Yusuf sangat menekankan pengawasan yang ketat terhadap para pemungut pajak, guna menghindari terjadinya penyelewengan seperti korupsi, tindak penindasan, dan lain sebagainya. Ia menganggap bahwa penghapusan penindasan dan jaminan kesejahteraan rakyat adalah sebagai tugas utama penguasa.

Dalam bukunya kitab al-Kharâj, Abu Yusuf menguraikan kondisi-kondisi untuk perpajakan, yaitu:

1. Charging a justifiable minimum (harga minimum yang dapat dibenarkan)

2. No oppression of tax-payers (tidak menindas para pembayar pajak)

3. Maintenance of a healthy treasury (pemeliharaan harta benda yang sehat)

4. Benefiting both government and tax-payers (manfaat yang diperoleh bagi pemerintah dan para pembayar pajak)

5. In choosing between alternative policies having the same effects on treasury, preferring the one that benefits tax-payers (pada pilihan antara beberapa alternatif peraturan yang memiliki dampak yang sama pada harta benda, yang melebihi salah satu manfaat bagi para pembayar pajak) (Indra Mohamad Ghazali, 2016).

\section{Konsep Perpajakan Menurut Ibnu Khaldun}

Dalam kitab Muqaddimahnya, Ibnu Khaldun terbilang cukup banyak membahas pendapatan negara yang didapatkan dari penduduknya. Dalam hal ini, untuk membiayai kemakmuran daulah. Dalam kitabnya ini, beliau banyak mengkritik tentang kehidupan daulah yang mewah dan penuh foya-foya yang mana berasal dari uang hasil pajak.

Dalam pasal ke-51 kitab Muqaddimah, Ibnu Khaldun juga memaparkan kebijakan pemungutan pajak. Kebijakan ini terinspirasi dari surat Thahir bin Al-Husain kepada putranya, Abdullah bin Thahir, ketika Al-Makmun mengangkat putranya itu menjadi gubenur di Riqqah, Mesir dan sekitarnya yang berisi pesan untuk mengurus kharaj (pajak) 
yang menjadikan rakyat lurus dan membagikannya diantara para pemiliknya dengan haq, adil, sama dan merata (Ibnu Khaldun, 2013).

Dalam pasal lain, Ibnu Khaldun juga menjabarkan bahwa ketika pendapatan dan gaji yang dibebankan atas rakyat itu sedikit, maka mereka bersemangat dan senang bekerja. Hasilnya akan banyak pembangunan dan semakin bertambah hasil dari semangat itu akibat sedikitnya beban. Ketika pembangunan telah banyak maka banyak juga jumlah gaji-gaji dan pendapatan-pendapatan itu. Akibatnya pajak juga menjadi banyak karena ia merupakan bagian dari pembangunan (Ibnu Khaldun, 2013).

Kutipan tersebut menjelaskan bahwa apabila pajak yang dibebankan kepada rakyat itu sedikit, maka rakyat akan bersemangat dan senang bekerja. Artinya, juga yang akan mendorong pertumbuhan ekonomi yang pada akhirnya Ibnu Khaldun juga memperhatikan produktivitas rakyat. Sebab, dengan sedikitnya beban dan produktivitas meningkat, maka penghasilan rakyat akan bertambah. Hal inilah jika penghasilan rakyat bertambah, maka bertambah pula pajaknya.

Menurut Ibnu Khaldun, ketika penghasilan pajak bertambah maka semakin besar peluang masyarakat untuk mendapatkan kehidupan yang sejahtera, karena hakikat dari fungsi pajak itu sendiri adalah untuk membantu masyarakat yang lemah yang membutuhkan yang sering disebut "distribution of welfare” (pemerataan kesejahteraan). Bagi pemerintah hal itu menjadi suatu "social benefit" (manfaat sosial).

Ibnu Khaldun memberikan opini bahwa fungsi pendapatan negara harus mengacu pada tingkat pajak yang optimum dengan alasan didasarkan pada prinsip perpajakan bahwa semakin rendah beban pajak maka semakin tinggi energi wajib pajak yang dapat dimanfaatkan untuk meningkatkan kegiatan-kegiatan yang produktif. Pembebanan pajak yang optimal akan memacu usaha-usaha kultural dan bisnis untuk tumbuh, sebab dengan tingkat pajak yang rendah itu mereka merasakan kepuasan yang maksimum dalam melakukan kegiatan ekonomi. Implikasinya, jika usaha-usaha tersebut berkembang, maka jumlah wajib pajaknya pun otomatis akan ikut meningkat. Dengan demikian, pendapatan pajak yang merupakan agregasi dari penetapan jumlah wajib pajak menjadi lebih tinggi. Dalam bahasa sekarang ini, argumentasi Ibnu Khaldun ini sama halnya dengan kurva laffer (Arif Hoetoro, 2007). 
Lebih lanjut Ibnu Khaldun menjelaskan jika pajak terlalu rendah, pemerintah tidak dapat menjalani fungsinya, karena pemerintah tidak bisa berjalan tanpa adanya dukungan finansial yang mumpuni, jika pajak terlalu tinggi, tekanan fiskal menjadi terlalu kuat, sehingga laba para pedagang dan produsen menurun dan menyebabkan hilangnya insentif mereka untuk bekerja. Maka dari itu penetapan pajak yang berprinsip keadilan merupakan suatu keharusan.

Pajak sangat mempengaruhi dan berdampak pada transaksi jual beli yang menyebabkan barang mahal, serta adanya mencari keuntungan yang lebih oleh para pedagang akibatnya sangat berdampak pada kestabilan harga serta merubah sifat konsumtif masyarkat yang semula sedang berubah menjadi masyarakat yang boros.

Penulis mengambil kesimpulan, bahwa dalam pernyataan di atas terdapat indikasi ketidak-setujuan Ibnu Khaldun terhadap adanya pajak yang dikenakan atas jual-beli atau saat ini disebut dengan PPN.

Dalam hal mekanisme pemungutan pajak, Ibnu Khaldun mengungkapkan bahwa perlu dewan atau departemen khusus yang mengurusi pajak dengan memiliki konsentrasi penuh dan komitmen yang tinggi untuk mengelola pajak tersebut. Dalam pandangan ini Ibnu Khaldun mengemukakan, Negara ada bagian-bagian dari pemerintah yang mengurusi masalah-masalah ekonomi ini yang terpenting diantaranya adalah masalah mengurus pajak.

Dalam bahasa Arab Ibnu Khaldun menamakan lembaga ini dengan (Diwaan al'Amal wa al-Jibayah) mengenai hakikat dan tugas dari lembaga ini Ibnu Khaldun mengatakan; bahwa pekerjaan umum dan perpajakan merupakan depertemen dalam pemerintahan yang bertugas menangani retribusi, menjaga dan melindungi hak-hak kerajaan dari segi pendapatan dan pengeluaran, mendata nama-nama seluruh personel militer dan menentukan besar kecilnya gaji mereka, dan menyerahkan upah dan gaji mereka pada waktunya. Pelaksanaan operasional tugas-tugas ini mengacu pada aturanaturan yang telah merumusan operasi pajak dengan bekerja sama dengan pegawai pemerintah (Ibnu Khaldun, 2013).

Dalam pandangannya Ibu Khaldun lebih lanjut menjelaskan bahwa badan yang mengurus pemungutan pajak ini baru terbentuk pertama kalinya di dalam negara ketika kekuatan serta kepentingan mereka di dalam berbagai aspek kedaulatan dan di dalam 
administrasi yang efesien telah tegak dengan kokoh. Dewan khusus yang dibentuk oleh pemerintah tersebut memiliki wewenang tertinggi dan mempunyai kebebasan mutlak untuk memungut, mengumpulkan dan memegang uang serta mengontrol kegiatan finansial dan kemudian mengeluarkannya sesuai dengan jumlah yang telah ditentukan dan tepat pada waktunya. Ini dikenal dengan al-Asyghal (manajer bagian keuangan) atau sekarang lebih kita kenal di Indonesia dengan Direktorat Jendral Pajak (Ibnu Khaldun, 2013).

Ibnu Khaldun juga menegaskan agar ada pengawasan terhadap petugas pajak sebagaimana dikutip dalam pasal ke-40; bahwa kadangkala dengan membagi para pekerja dan para penarik dan mengawasi mereka karena kerajaan memandang bahwa mereka ini telah menghasilkan sesuatu yang bermanfaat dari harta pajak yang tidak dapat ditampakkan hitungannya (Ibnu Khaldun, 2013).

Penulis mengambil kesimpulan hal ini dilakukan untuk dapat memantau pendapatan pajak serta pendistribusiannya secara adil dan benar. Selain itu juga mencegah terjadinya penyelewengan atau tindak korupsi serta pemerasan.

\section{Relevansi Konsep Perpajakan Menurut Abu Yusuf dan Ibnu Khaldun Terhadap Perekonomian di Indonesia}

Pajak merupakan sumber pendapatan negara terbesar. Anggaran pembangunan dan operasional pemerintahan mempunyai ketergantungan yang besar pada pajak. Berbicara pajak bukan hanya mengenai pencapaian target tetapi juga tata kelola pajak, yaitu aturan mengenai pajak, sistem perpajakan, petugas pajak, sampai kepada potensi pajak yang dapat dioptimalkan (Indra Mohamad Ghazali, 2016).

Menurut Abu Yusuf, metode pajak dengan proporsional bisa memberikan peningkatan pendapatan negara dari segi pajak tanah dan juga bisa mendorong para penanam dalam meningkatkan produksinya. Sistem ini dinilai memberikan rasa adil serta dapat menjadi automatic stabilizier untuk perekonomian yang selanjutnya tidak akan membuat perekonomian berfluktuasi terlalu tajam. Dengan demikian dapat terlihat dari paparan diatas bahwa Abu Yusuf menginginkan adanya keadilan bagi seluruh warga negara. Di Indonesia sendiri tarif pajak sangat beragam, ada tarif progresif yang di terapkan pada $\mathrm{PPh}$, proporsional yang diterapkan pada PBB dan PPN. 
Pemungutan pajak di Indonesia mengacu pada sistem self assessment. Sistem self assesment bisa diartikan memberikan kepercayaan dan tanggungjawab kepada wajib pajak untuk menghitung, membayar serta melaporkan secara mandiri jumlah besaran pajak yang harus dibayarkan.

Sistem ini jika direlevansikan dengan masa Abu Yusuf sama dengan sistem taqbil. Penerapan sistem ini ikut menyuburkan praktik korupsi pajak di Indonesia. Jika sebuah perusahaan membayar pajak yang jumlahnya terlalu kecil kalau dibandingkan dengan penampilannya, maka petugas pajak yang menanganinya bisa dengan mudah cuci tangan, yakni hitungan pajak itu dibuat sendiri oleh pihak perusahaan.

Sistem yang dikemukakan oleh Abu Yusuf jika diterapkan pada masa sekarang masih sangat relevan, lebih-lebih self assesment system yang saat ini berlaku di Indonesia memungkinkan terjadi kecurangan-kecurangan oleh wajib pajak.

Jika dibuat relevansi dan hubungan usyur dengan pajak bea cukai saat ini, maka dapat disimpulkan beberapa hal berikut:

1. Usyur merupakan bentuk pajak atas barang niaga yang dibayarkan kepada negara dengan tujuan perlindungan dan kemashlahatan umum.

2. Usyur merupakan bentuk pajak benda dengan melihat pribadi pemiliknya, sebab jumlah yang dikenakan akan berbeda sesuai agamanya, berbeda dengan pajak bea cukai saat ini yang tidak melihat sisi agama pemiliknya, Dalam hal ini, usyur yang dikenakan atas Muslim, bukan hanya menjadi pajak, namun merupakan kewajiban zakat atas harta niaganya.

3. Usyur adalah bentuk pajak tidak langsung karena ia dikenakan atas barang perniagaan yang pembayarannya dilakukan pada pos perbatasan negara, baik pintu masuk maupun pintu keluar sebagaimana pajak bea cukai saat ini (Nurul Huda \& Ahmad Muti, 2011).

Abu Yusuf sangat menekankan pengawasan yang ketat terhadap para pemungut pajak, guna menghindari terjadinya penyelewengan seperti korupsi, tindak penindasan, dan lain sebagainya. Ia menganggap bahwa penghapusan penindasan dan jaminan kesejahteraan rakyat adalah sebagai tugas utama penguasa. 
Penulis berargumen dengan adanya kriteria yang ketat dapat menjaga kualitas petugas pajak, hal ini sesuai dengan semakin maraknya praktik korupsi yang terjadi di Indonesia.

Pandangan Abu Yusuf tersebut, selaras dengan pendapat Ibnu Khaldun yang juga mengharuskan adanya pengawasan yang ketat terhadap mekasnisme pemugutan serta petugas pajak untuk menghindari adanya penyelewengan terhadap pajak dan pemerasan pajak.

Jauh sebelum Adam Smith (w.1790) yang terkenl dengan canons of taxation atau kaidah-kaidah perpajakannya (persamaan, kepastian, keyakinan pembayaran dan ekonomi dalam pengumpulan), Ibnu Khaldun telah menekankan prinsip perpajakannya dengan sangat jelas dalam Muqaddimah. Beliau menekankan adanya persamaan, kenetralan dan kemudahan. Selain itu ditegaskan pula adanya keadilan.

Ibnu Khaldun juga mengungkapkan apabila pajak yang dibebankan kepada rakyat itu sedikit, maka rakyat akan bersemangat dan senang bekerja. Beliau memperhatikan produktivitas rakyat. Sebab, dengan sedikitnya beban dan produktivitas meningkat, maka penghasilan rakyat akan bertambah. Hal inilah jika penghasilan rakyat bertambah, maka bertambah pula pajaknya.

Jika direlevansikan dengan sistem perekonomian Indonesia saat ini, menurut penulis, dengan sedikitnya beban pajak akan meningkatkan semangat masyarakat di dalam berinovasi dan bekerja. Tingkat produktivitas pun akan semakin naik.

Ibnu Khaldun juga menuliskan bahwa pajak harus dikenakan secara proposional, sesuai dengan kemampuan pembayar pajak, sedangkan pajak tak langsung seperti PPN (Pajak Pertambahan Nilai) yang mengikis daya beli masyarakat hendaknya ditiadakan, kerena dengan peniadaan pajak PPN akan menurunkan harga barang secara spontan, sehingga permintaan akan meningkat. Dengan adanya interaksi antara permintaan dan penawaran akan menciptakan keuntungan pada perusahaan, yang selanjutnya akan di pungut pajaknya oleh administrasi perpajakan yang rapi dan jujur, sehingga penerimaan negara pun menjadi meningkat (Jhonaidi, 2016).

Penghapusan PPN jika direlevansikan dengan perekonomian di Indonesia saat ini, akan berdampak pada meningkatnya penjualan. Sebab dengan turunnya harga akan membuat permintaan meningkat. 


\section{SIMPULAN}

Dari seluruh rangkaian pembahasan tersebut, relevansi konsep perpajakan menurut Abu Yusuf dan Ibnu Khaldun terhadap perekonomian di Indonesia, dapat diambil beberapa simpulan di bawah ini :

1. Konsep pajak Menurut Abu Yusuf dan Ibnu Khaldun :

a. Menurut Abu Yusuf :

1) Prinsip-prinsip perpajakan: kesanggupan membayar, pemberian waktu yang longgar bagi pembayar pajak, dan sentralisasi pembuatan keputusan dalam administrasi pajak.

2) memberlakukan sistem muqasamah, yaitu sistem pemungutan pajak yang diberlakukan berdasarkan tingkat kemampuan dan persentase penghasilan atau pajak proporsional.

3) Abu Yusuf menolak praktik taqbil atau self assesment system.

4) Abu Yusuf berpendapat bahwa harus ada kriteria khusus bagi pengelola pajak.

b. Menurut Ibnu Khaldun :

1) Apabila pajak yang dibebankan kepada rakyat itu sedikit, maka rakyat akan bersemangat dan senang bekerja.

2) Fungsi pendapatan negara harus mengacu pada tingkat pajak yang optimum.

3) Tingginya biaya barang yang dikenakan pajak akan mempengaruhi jual beli dan harga barang.

4) Perlu dewan atau departemen khusus yang mengurusi pajak dengan memiliki konsentrasi penuh dan komitmen yang tinggi untuk mengolah pajak tersebut.

2. Relevansi konsep perpajakan menurut Abu Yusuf dan Ibnu Khaldun terhadap perekonomian di Indonesia:

a. Sistem muqasamah jika diterapkan pada masa sekarang masih sangat relevan, lebih-lebih self assesment system yang saat ini berlaku di Indonesia memungkinkan terjadi kecurangan-kecurangan oleh wajib pajak.

b. Usyur yang berlaku pada masa Abu Yusuf jika direlevansikan pada masa sekarang maka memiliki beberapa kesamaan dengan pemungutan pajak bea cukai.

c. Dengan adanya kriteria yang ketat sebagaimana pendapat Abu Yusuf dan Ibnu Khaldun, dapat menjaga kualitas petugas pajak di Indonesia. 
d. Dengan sedikitnya beban pajak akan meningkatkan semangat masyarakat di dalam berinovasi dan bekerja. Tingkat produktivitas pun akan semakin naik.

e. Penghapusan PPN jika direlevansikan dengan perekonomian di Indonesia saat ini, akan berdampak pada meningkatnya penjualan. Sebab dengan turunnya harga akan membuat permintaan meningkat.

\section{DAFTAR PUSTAKA}

Abdullah, Boedi. Peradaban Pemikiran Ekonomi Islam. Bandung: Pustaka Setia, 2010.

Chamid, Nur. Jejak Langkah Sejarah Pemikiran Ekonomi Islam. Yogyakarta: Pustaka Pelajar, 2010.

Departemen Agama RI. Al Qur'an dan terjemahnya. Bandung: Syaamil Qur'an, 2011.

Devano, Sony. Siti Kurnia Rahayu. Perpajakan Konsep, Teori dan Isu. Jakarta:Kencana, 2006.

Fahmi, Gus. Pajak Menurut Syariah. Jakarta: Raja Grafindo Persada, 2007.

Hoetoro, Arif. Ekonomi Islam, Pengantar Analisis Kesejarahan dan Metodologi. Malang: Badan Penerbit Fakultas Ekonomi Universitas Brawijaya, 2007.

Huda, Nurul. Ahmad Muti. Keuangan Publik Islami, Pendekatan Al-Kharaj (Imam Abu Yusuf). Bogor: Ghalia Indonesia, 2011.

Karim, Adiwarman Azwar. Sejarah Pemikiran Ekonomi Islam. Jakarta:PT.RadjaGrafindo Persada, 2004

Khaldun, Ibnu. Muqaddimah. Edisi Indonesia. Penerjemah Masturi Ilham, dkk. Jakarta: Pustaka Al-Kautsar, 2013.

Kufy (Al) Baghdadi, Abu Yusuf Ya'qub bin Ibrahim bin Habib Al-Anshary. Al-Kharaj. Riyadh: Dar As-Salam, 2016.

Majid, M. Nazori. Pemikiran Ekonomi Islam Abu Yusuf Relevansinya dengan Ekonomi Kekinian. Jakarta: Pusat Studi Ekonomi Islam, 2003.

Maksum, Moh. Asra. Musirin. Pemikiran Kiai As'ad Tentang Ekonomi dalam Islam. Surabaya: CV. Salsabila Putra Pratama, 2013. 
Nasution, Edwin dkk. Pengenalan Eklusif Ekonomi Islam. Jakarta: PRENADA MEDIA GROUP, 2015. Cet-5.

Rahayu, Siti Kurnia. Perpajakan Indonesia Konsep dan Aspek Formal. Bandung: Graha Ilmu, 2009.

Sholeh, Abdul Rahman. Pendidikan Agama dan Pengembangan untuk Bangsa. Jakarta: PT. RajaGrafindo Persada, 2005.

Abdul Hasis, "Pemikiran Ibnu Khaldun Tentang Fungsi dan Mekanisme Pajak" (Skripsi - Universitas Islam Negeri Sultan Syarif Kasim, Riau, 2010), 11. Dalam https://repository.uin-suska.ac.id.

Bahrul Ulum "Konstribusi Ibnu Khaldun Terhadap Perkembangan Ekonomi Islam" (Jurnal Ekonomi Syari'ah -- IAI Al-Qalam, Gondanglegi Malang, September 2016).

Dalam http://ejournal.alqolam.ac.id/index.php/iqtishodia/articledownload/62/68.

http://ceritaperpajakanindonesia.blogspot.co.id/2012/05/permasalahanpajak-diindonesia.html/m=1.

https://id.m.wikipedia.org/wiki/Pengampunan_pajak.

Indra Mohamad Ghazali, "Pajak Menurut Ulama Abu Yusuf dan Relevansinya di Zaman Sekarang", dalam : https://assalam1986blog.wordpress.com/2016/01/26/pajakmenurut-ulama-abu-yusuf-dan-relevansinya-di-zaman-sekarang/

Jhonaidi, "Relevansi Pajak Menurut Pemikiran Ekonomi Islam Ibnu Khaldun", dalam : http://www.kompasiana.com/jhoned23/12/14/2016.

Muhammad Fauzan, “Konsep Perpajakan Menurut Abu Yusuf”, Human Falah, Vol. 4, No. 2 (Juli-Desember 2017), 179-180. Dalam http://repository.uinsu.ac.id/1674.

Sayri, “Konsep Pengelolaan Pajak Yang Adil Perspektif Ibnu Khaldun”. (Skripsi - IAIN Palangka Raya, Palangka Raya, 2016). Dalam https://digilib.iainpalangkaraya.ac.id. 